\title{
KNOWLEDGE OF EMERGENCY CONTRACEPTIVES AMONG WOMEN OF REPRODUCTIVE AGE GROUP
}

\author{
Singh Rimi ${ }^{1}$, Himabindu Nagulapally2 ${ }^{2}$ Shrivastava Abhijeet ${ }^{3}$
}

${ }_{1}^{1}$ Assistant Professor, Department of Obstetrics and Gynaecology, Indira Gandhi Medical College and Research Institute, Puducherry. 2 Associate Professor, Department of Obstetrics and Gynaecology, Indira Gandhi Medical College and Research Institute, Puducherry. ${ }^{3}$ Senior Resident, Department of Paediatrics, Sri Lakshmi Narayan Institute of Medical Sciences, Puducherry.

\section{ABSTRACT}

\section{BACKGROUND}

As per data from WHO, 21.6 million unsafe abortions occurred globally in 2008, out of which 47,000 women died from abortionrelated complications, contributing to $13 \%$ of global maternal mortality.(1) Emergency contraceptive can be used after intercourse to prevent pregnancy in case of unprotected intercourse, contraceptive failure or sexual assault. A considerable proportion of these abortions can be prevented by the timely use of emergency contraception.

\section{OBJECTIVES}

To study the knowledge of emergency contraceptives among women of reproductive age group.

\section{METHODS}

This is a government hospital-based prospective study done for a period of 3 months. The study included 500 women of reproductive age group (16 years to 40 years) attending OPD of Obstetrics and Gynaecology Department of IGMC and RI, Pondicherry. A predesigned questionnaire is provided to women asking about awareness regarding emergency contraceptives.

\section{RESULTS}

Majority of them were between 20 and 30 years of age, 59.6\% were from urban background and $86.8 \%$ were educated; $66 \%$ of them had used regular method of contraception some time in their life, but the awareness level of emergency contraceptives was found to be only $5.4 \%$ of which only $2 \%(n=10)$ had ever used emergency contraceptives.

\section{CONCLUSION}

Emergency contraceptives is an effective means of preventing unwanted pregnancies, but unfortunately majority of women lack awareness about the emergency methods. Efforts should be focused on providing health education regarding EC among females through media and health professionals.

\section{KEYWORDS}

Emergency Contraception.

HOW TO CITE THIS ARTICLE: Rimi S, Nagulapally H, Abhijeet S. Knowledge of emergency contraceptives among women of reproductive age group. J. Evolution Med. Dent. Sci. 2016;5(34):1909-1912, DOI: 10.14260/jemds/2016/452

\section{INTRODUCTION}

Unintended pregnancies continue to be a significant public health issue and poses a major challenge to reproductive health of women and particularly among young adults in developing countries. The World Health Organisation (WHO) estimated that one woman dies every 8 minutes due to unsafe abortion in developing countries.[2] $78 \%$ of pregnancies in India are unplanned and at least $25 \%$ are unwanted.

Unprotected sexual intercourse and method failure leads to unwanted pregnancies (EC) promises to be useful in such cases by preventing unwanted pregnancies from unprotected sex. Emergency contraceptives is defined as any method women can use after intercourse to prevent pregnancy.(3)

Emergency contraceptives is the only method women can use to prevent pregnancy after they have had unprotected sexual intercourse, have experienced contraceptive failure

Financial or Other, Competing Interest: None.

Submission 09-03-2016, Peer Review 02-04-2016,

Acceptance 11-04-2016, Published 28-04-2016.

Corresponding Author:

Dr. Rimi Singh,

Door No. 43, 3rd Main Raod,

Kumaran Nagar Ext., Lawspet,

Puducherry.

E-mail: drsamirnayak@gmail.com

DOI: $10.14260 /$ jemds/2016/452 have remembered too late that they have forgotten to take birth control pills or victims of sexual assault. Emergency contraceptives is sometimes referred to as "morning after" or "Post coital" contraception.

It consists of high doses of the same hormones used in oral contraceptive pills.(4) Emergency contraceptives include use of combination pill (Oestrogen and progesterone) or progestin only pills, mifepristone, centchroman or insertion of IUD. The emergency contraceptive pills are effective only if used within 72-120 h. of unprotected sex.

Although the hormonal emergency contraceptive pills have been technically available since 1960 through off-label use of OC pills, they still remain a relatively unknown and underused method. The hormonal emergency contraception concept was introduced in India in 2000. In 2003, emergency contraceptive pills was introduced in health centres and hospitals by the name of emergency contraceptive pills in India. It has levonorgestrel $(0.75)$. Two pills are to be takenfirst within 72-120 hours of unprotected sexual intercourse and another after 12 hours of taking the first pill.

Current recommendation states that two pills can be taken together also. The present study was undertaken to ascertain the knowledge and awareness among reproductive aged females attending outpatient department. 


\section{OBJECTIVES}

To study the knowledge of emergency contraceptives among women of reproductive age group.

\section{METHODS}

This is a hospital-based prospective study done for a period of 3 months (2015) from March to May; 500 women in reproductive age group (16 years to 40 years) attending the OPD of Obstetrics and Gynaecology Department of IGMC and RI, Pondicherry, were included in the study. Informed consent was taken from all women. Before starting the interview, a brief clarification about the meaning and types of emergency contraceptives methods available was given to each of the study participants to make it clear that we are asking about emergency contraceptives and not regular contraceptives. Each interview lasted between 15 to 20 minutes. The questionnaire covered the demographic characters, use of regular contraceptive and awareness and use of EC.

\section{RESULTS}

Table 1 shows the demographic characters of the women studied. Overall, 500 female patients in the reproductive age group were enrolled in the study. Majority of them were between 20 and 30 years of age, 59.6\% were from urban background and $86.8 \%$ were educated; $63 \%$ were housewives, $58.4 \%$ had 1 living children and were potential target for contraception.

\begin{tabular}{|c|c|c|}
\hline \multirow{2}{*}{ Characteristics } & \multicolumn{2}{|c|}{$(n=500)$} \\
\hline & No. & $\%$ \\
\hline \multicolumn{3}{|l|}{ Age } \\
\hline$<20$ & 20 & $4 \%$ \\
\hline $20-30$ & 340 & $68 \%$ \\
\hline$>30$ & 140 & $28 \%$ \\
\hline \multicolumn{3}{|l|}{ Residence } \\
\hline Urban & 298 & 59.6 \\
\hline Rural & 202 & 40.4 \\
\hline \multicolumn{3}{|l|}{ Occupation } \\
\hline Housewife & 315 & 63.0 \\
\hline Earning & 185 & 37.0 \\
\hline \multicolumn{3}{|l|}{ Educational Level } \\
\hline Illiterate & 66 & 13.2 \\
\hline School (Any level) & 234 & 46.8 \\
\hline Graduate & 200 & 40 \\
\hline \multicolumn{3}{|l|}{ Marital Status } \\
\hline Married & 476 & 95.2 \\
\hline $\begin{array}{c}\text { Separated } \\
\text { Unmarried }\end{array}$ & 24 & 4.8 \\
\hline \multicolumn{3}{|l|}{ Parity } \\
\hline 1 & 292 & 58.4 \\
\hline 2 & 186 & 37.2 \\
\hline 3 or more & 22 & 4.4 \\
\hline \multicolumn{3}{|l|}{ Religion } \\
\hline Hindu & 336 & 67.2 \\
\hline Muslims & 102 & 20.4 \\
\hline Christians & 62 & 12.4 \\
\hline Others & 0 & 0 \\
\hline
\end{tabular}

As mentioned in Table 2 only $29 \%$ of the population was using regular method of contraception and $37 \%$ had used some form of contraception over some period of time. Condoms were the most commonly used method; $28.8 \%$ of the patients had undergone MTP.

\begin{tabular}{|c|c|c|c|}
\hline 1. & Use of a Contraceptive & Number & $\mathbf{( \% )}$ \\
\hline & Regular & 145 & $29 \%$ \\
\hline & Irregular & 185 & $37 \%$ \\
\hline & None & 170 & $34 \%$ \\
\hline 2 & Contraceptive & & \\
\hline & Condoms & 200 & $40 \%$ \\
\hline & Cu-T & 30 & $6 \%$ \\
\hline & Pills & 60 & $12 \%$ \\
\hline & Natural method & 10 & $3 \%$ \\
\hline & Permanent method & 35 & $7 \%$ \\
\hline 3. & Never used & 165 & $34 \%$ \\
\hline & History of MTP & & \\
\hline & Once & 120 & $24 \%$ \\
\hline & Twice & 24 & $4.8 \%$ \\
\hline
\end{tabular}

Table 2: Contraceptive and MTP Practices $(n=500)$

Table 3 shows that most of the study subjects lack the knowledge about emergency contraceptives methods. Only $5.4 \%$ of participants were aware of emergency contraceptives and among them only $2 \%$ had ever used emergency contraceptives. When asked about the source of their knowledge, they mentioned friends/family members and health workers as the main source. Most of them did not know about how it works. Regarding availability, most of them knew that it is available in the pharmacy.

\begin{tabular}{|c|c|c|}
\hline \multirow[t]{2}{*}{$\begin{array}{l}\text { Knowledge about Emergency } \\
\text { Contraceptives }\end{array}$} & \multicolumn{2}{|c|}{$\begin{array}{l}\text { Studied } \\
\text { Females } \\
(\mathrm{n}=500)\end{array}$} \\
\hline & No. & $\%$ \\
\hline \multicolumn{3}{|l|}{ Ever heard about EC } \\
\hline Yes & 27 & 5.4 \\
\hline No & 473 & 94.6 \\
\hline \multicolumn{3}{|l|}{ Ever used EC } \\
\hline Yes & 10 & 2 \\
\hline No & 17 & 3.4 \\
\hline \multicolumn{3}{|l|}{ EC methods act as abortifacient } \\
\hline Yes & 2 & 0.4 \\
\hline No & 5 & 1 \\
\hline Don't know & 20 & 4 \\
\hline \multicolumn{3}{|l|}{ Source of knowledge about EC methods } \\
\hline TV & 0 & \\
\hline Newspaper/Magazines/Internet & 0 & \\
\hline Friends/Family member & 15 & 3 \\
\hline Health facilities & 12 & 2.4 \\
\hline Others & 0 & 0 \\
\hline \multicolumn{3}{|l|}{ Legality of EC in Puducherry } \\
\hline Legal & 27 & 5.4 \\
\hline Illegal & 0 & 0 \\
\hline Not known & 0 & 0 \\
\hline \multicolumn{3}{|c|}{ Availability of EC methods in Puducherry } \\
\hline Available & 27 & 5.4 \\
\hline Unavailable & 0 & 0 \\
\hline Not known & 0 & 0 \\
\hline $\begin{array}{r}\text { Table 3: Knowledge about Emerg } \\
\text { among the Study }\end{array}$ & Sont & tives \\
\hline
\end{tabular}

As presented in Table 4 with regards to the usage of emergency contraceptives, only $2 \%(n=10)$ of the women had ever used emergency contraceptive pills and they used it to prevent pregnancy. The side effects reported were few. 


\begin{tabular}{|c|c|c|c|}
\hline 1. & Method Used & Number & $\%$ \\
\hline & EC Pills & 10 & 100 \\
\hline & IUD & 0 & 0 \\
\hline & Other method & 0 & 0 \\
\hline \multirow[t]{4}{*}{2.} & $\begin{array}{l}\text { Awareness about time limit for } \\
\text { taking EC after unprotected } \\
\text { intercourse }\end{array}$ & & \\
\hline & Immediately & 0 & 0 \\
\hline & Up to $12 \mathrm{hrs}$. & 7 & $70 \%$ \\
\hline & Up to $72 \mathrm{hrs}$. & 3 & $30 \%$ \\
\hline \multirow[t]{4}{*}{3.} & Side effects & & \\
\hline & Vomiting & 2 & $20 \%$ \\
\hline & Headache & 0 & 0 \\
\hline & Nil & 8 & $80 \%$ \\
\hline \multirow[t]{3}{*}{4.} & Perceived usefulness & & \\
\hline & Useful & 10 & 100 \\
\hline & Not useful & 0 & - \\
\hline
\end{tabular}

\section{DISCUSSION}

In India where rates of unplanned pregnancies and illegal abortions are high, it is estimated that $78 \%$ pregnancies are unplanned and $25 \%$ are definitely unwanted, despite a 'National Family Welfare Programme' and widespread efforts by the government.[5] Introduction of emergency contraceptives through government supply has a potential to change the scenario. The hormonal emergency contraceptives pills reduce the risk of pregnancy by up to 95\% and EC IUD insertion reduces such risk by $99.9 \% .{ }^{[6]}$

The present study shows the knowledge of emergency contraceptives among the participants are quite less (5.4\%). This is comparable to other Indian studies, which showed similar results. A study carried out by Tripathi et al(7) in New Delhi showed that practically none of their patients were aware of emergency contraceptives. Reeti et al(8) studied 100 subjects, of which only one woman was aware of emergency contraceptive pills. However, Takkar et al found slightly increased awareness of emergency contraceptives (11.2\%) among educated women in India. ${ }^{(9)}$

Glei et al studied a population of 1290 women aged 17 50 years in California of whom $28 \%$ had heard of ECP.(9,10) A study in USA revealed that only $23 \%$ young women knew about ECP. In South Africa, a similar study revealed $17 \%$ awareness among young women.(11),(12) Amalba et al(13) study showed the awareness of EC among reproductive women in Ghana found to be $69 \%$, which is much higher than the previous studies. Such differences in the awareness level in different countries may be due to their culture differences and government policies.

In our study, $5.4 \%$ of patients who were aware of emergency contraceptives had heard from their friends or health workers and not from social media. In India, EC pills are now available over the counter in the private sector as well as government supply. Anybody can procure this even without doctor's prescription. But the only thing which is lacking is the awareness and knowledge among the females about emergency contraceptives, how it works, when to take and about safety and potential uses.
The health workers and health professionals can play a larger role in informing women about emergency contraceptives. Though contraceptive awareness among women is high, but emergency contraceptives is an area where much work needs to be done and efforts must be taken through promotional and educational approach to make more and more women aware of emergency contraceptives.

\section{CONCLUSION}

Emergency contraceptives is an effective means of preventing unwanted pregnancies without much side effects, but unfortunately majority of women in reproductive age group lack awareness about the emergency methods. Efforts should be focused on providing health education regarding emergency contraceptives among females with focus on available methods, timing of use and health effects through media and health professionals.

\section{REFERENCES}

1. Unsafe abortion: global and regional estimates of the incidence of unsafe abortion and associated mortality in 2008 Sixth edition. Geneva: World Health Organization; 2011. Available online at

http://whqlibdoc.who.int/publications/2011/9789241 501118_eng.pdf.

2. World Health Organisation. Unsafe abortion. Global and regional estimates of the incidence of unsafe abortion and associated mortality in $20035^{\text {th }}$ ed. Geneva : World Health Organisation, 2007.

http://whqlibdoc.who.int/publications/2007/9789241 596121_eng.pdf.

3. Consensus statement on emergency contraception. Contraception 1995;52(4):211-3.

4. Delbanco SF, Mauldon J, Smith MD. Little knowledge and limited practice: emergency contraceptive pills, the public and the obstetrician-gynaecologist. Am J Obst Gynaecol 1997;89(6):1006-11.

5. Emergency contraception. Training manual for health care providers. WHO collaborative centre for research in human reproduction, dept of obs and gynae: AIIMS, New Delhi, 2000;17-8.

6. Harper C Cynthia, Corinne H Rocca, Philip D Darney. Tolerabillity of levonorgesterol emergency contraceptions in adolescents. Am J Obstet Gynaecol 2004;191(4):1158-63.

7. Tripathi R, Rathore AM, Sachdev J. Emergency contraception: knowledge, attitude and practice among health care providers in North India. J Obstet Gynaecol Res 2003;29(3):142-6.

8. Mehra R, Goel P, Dua D, et al. Knowledge of emergency contraception among women coming for induced abortion. J obstet gynaecol India 2006;56:233-5.

9. Takkar N, Goel P, Saha PK. Contraceptive practices and awareness of emergency contraception in educated working women. Indian J Med Sci 2005;59(4):143-9.

10. Glei DA. Measuring contraceptive use patterns among teenage and adult women. Fam Plann Perspect 1999;31(2):73-80. 
11. Smith B, Gurney E, Aboulcla L. Emergency contraception: a survey of women's knowledge and attitudes. Br J Obstet Gynaecol 1996;103(11):1109-16.

12. Mqhayi MM, Smit JA, McFadyen ML, et al. Missed opportunities: emergency contraception utilization by young South African women. Afr J Reprod Health 2004;8(2):137-44.
13. Amalba A, Mogre V, Appiah NAM, et al. Awareness, use and associated factors of emergency contraceptive pills among women of reproductive age (15-49years) in tamale ghana. BMC Womens health 2014;14:114. 